\title{
Association between dietary protein intake and prostate cancer risk: evidence from a meta-analysis
}

\author{
Ye Mao, Yan Tie and Jing Du*
}

\begin{abstract}
Background: Many studies were conducted to explore the relationship between dietary protein intake and risk of prostate cancer, obtaining inconsistent results. Therefore, this study aims to comprehensively explore the predicted role of dietary protein intake for risk of prostate cancer.

Methods: Databases of Web of Knowledge, PubMed, Chinese National Knowledge Infrastructure (CNKI), and Wan Fang Med Online were searched up to August 30, 2017. Eligible studies were included based on our definite inclusion criteria. Summarized relative risk (RR) and corresponding $95 \%$ confidence interval (Cl) were pooled with a random effects model. Sensitive analysis and publication bias were performed.

Results: At the end, a total of 12 articles comprising 13,483 prostate cancer cases and 286,245 participants were included. The summary RR and $95 \% \mathrm{Cl}$ of the highest protein intake compared to those with the lowest protein intake on prostate cancer risk were $0.993(95 \% \mathrm{Cl}=0.930-1.061)$, with no between-study heterogeneity found $\left(P^{2}=0\right.$. $0 \%, P=0.656)$. Moreover, the association was not significant on prostate cancer risk with animal protein intake [RR $=1.001,95 \% \mathrm{Cl}=0.917-1.092]$ or vegetable protein intake $[\mathrm{RR}=0.986,95 \% \mathrm{Cl}=0.904-1.076]$. The results were not changed when we conducted subgroup analysis by study design, cancer type, or geographic locations. We did not detect any publication bias using Egger's test $(P=0.296)$ and funnel plot.
\end{abstract}

Conclusion: Our study concluded that protein intake may be not associated on prostate cancer.

Keywords: Dietary, Protein intake, Prostate cancer, Meta-analysis

\section{Background}

Prostate cancer is one of the most common cancer among men, and nearly a million new cases are diagnosed worldwide [1]. In total, the incidence rate of prostate cancer in western countries is higher than that in other countries $[2,3]$. The reason for this status may be the differences in dietary intake $[3,4]$. In western countries, they usually eat foods rich in calories, saturated fats, as well as animal protein, and so on. However, lower intake of fruits, vegetables, and whole grains lead to diet imbalance. Therefore, these western diets are not only related to prevalence of obesity [5] but also can directly change the known parameters to promote the growth of prostate cancer [6].

\footnotetext{
* Correspondence: du___ing@163.com

Cancer Center, West China Hospital, West China Medical School Sichuan

University, No. 37, Guoxue Alley, Chengdu 610041, Sichuan Province, China
}

Protein is macromolecules made of amino acids and have basic functions in all known biologic processes. As we all know, protein contains 22 known amino acids. Of these, 9 essential amino acids could not be synthesized in the body [7]. Therefore, humans must eat some levels of foods which are rich in protein, to obtain the essential amino acid that is required for new protein synthesis. The protein usually comes from animal meats, plants such as soy, and dairy products [7]. Many publications were performed to assess the association about prostate cancer with high-protein intake. However, the effect on prostate cancer from different studies remains to be controversial. To address this question, we sought to perform this comprehensive meta-analysis to reflect the current totality of evidence on the subject.

(c) The Author(s). 2018 Open Access This article is distributed under the terms of the Creative Commons Attribution 4.0 International License (http://creativecommons.org/licenses/by/4.0/), which permits unrestricted use, distribution, and reproduction in any medium, provided you give appropriate credit to the original author(s) and the source, provide a link to the Creative Commons license, and indicate if changes were made. The Creative Commons Public Domain Dedication waiver (http://creativecommons.org/publicdomain/zero/1.0/) applies to the data made available in this article, unless otherwise stated. 


\section{Methods}

Literature search

Articles were searched from the electronic searches of Web of Knowledge, PubMed, Chinese National Knowledge Infrastructure (CNKI), and Wan Fang Med Online, with the strategy of 'protein' OR 'nutrition' OR 'diet' AND 'prostate cancer' OR 'prostate oncology' as recent as August 30, 2017. Moreover, the bibliographies of searched publications were cross-referenced in order to identify additional articles.

\section{Inclusion and exclusion criteria}

The inclusion criteria in this meta-analysis were (1) observational studies or experimental studies; (2) studies assessing the association about prostate cancer with protein intake; (3) the relative risk (RR) with the corresponding 95\% confidence interval (CI) in the relation was available, or could be calculated basing on relevant data; (4) reporting the studies on humans; and (5) studies published in English language or Chinese language.

By contrast, the studies were excluded if they (1) reported on animal studies or cell studies; (2) were reviews, letter to the editors, or comments; and (3) contained insufficient data for statistical analysis.

\section{Data extraction}

The following required data were abstracted according to a predefined standardized form: the first author's last name; publication years; prostate cancer type; protein (total protein, animal protein, or vegetable protein); region for the study; study type; mean age or age range; follow-up duration; cases and participants; RR with 95\% CI for the association between dietary protein intake and risk of prostate cancer; and adjustment for covariates. Two independent individuals extracted the data and the disagreements were resolved by a third reviewer.

\section{Statistical analysis}

RR with the corresponding 95\%CI was combined to calculate the summary results [8]. A chi-square test $I^{2}$ statistic was used to assess the heterogeneity [9], and $I^{2}<$ $25 \%, I^{2}=25-50 \%, I^{2}>50 \%$ suggested low, moderate, and high heterogeneity [10]. All the analysis used random effects model as pooled results. Sensitivity analysis was performed to find if some single study affected the overall results or not. Egger's test [11] and Begg's funnel plots [12] were utilized to examine the publication bias. Stata 12.0 software (STATA, College Station, TX, USA) was used to carry out the statistical analyses. $P<0.05$ defined statistical significance.

\section{Results}

Search results and characteristics of studies

Figure 1 shows the flow diagram. The initial screening identified 43,921 articles from Web of Knowledge,
61,591 articles from PubMed, 341 articles from Chinese National Knowledge Infrastructure (CNKI), and 412 articles from Wan Fang Med Online. After the duplicated publications from different databases were excluded and the title and abstract reviewed, 41 articles were further reviewed for full text. There are 2 additional articles that were searched from the references of reviewed articles. Eleven articles that did not obtain RR and 95\%CI, 12 review articles, 6 animal or cell articles, and 2 letters to the editors were further excluded. Therefore, 12 articles [13-24] were left for this study. Eight studies were cohort design, 5 studies were case-control design, and the remaining 1 study was RCTs. Six studies came from Europe, 5 from America, and 1 from Asia. All of the suitable studies included 13,483 prostate cancer cases and 286,245 participants. The characteristics of the included studies are summarized in Table 1.

\section{Meta-analysis}

In the overall analysis, the summary RR and 95\%CI of the highest protein intake compared to those with the lowest protein intake on prostate cancer risk were 0.993 $(95 \% \mathrm{CI}=0.930-1.061)$, with no between-study heterogeneity found $\left(I^{2}=0.0 \%, P=0.656\right)$ (Fig. 2).

In the stratified analysis by protein type, the association was significant on prostate cancer risk neither in animal protein intake $[R R=1.001,95 \% C I=0.917-1.092]$ nor in vegetable protein intake $[R R=0.986,95 \% \mathrm{CI}=$ 0.904-1.076]. There is no significant association found either in cohort studies $[\mathrm{RR}=1.080,95 \% \mathrm{CI}=0.964-$ $1.209]$ or in case-control studies $[\mathrm{RR}=0.960,95 \% \mathrm{CI}=$ 0.874-1.055]. The summary RRs (95\%CI) of the highest protein intake compared to the lowest protein intake were $1.263(95 \% \mathrm{CI}=0.953-1.674)$ on prostate cancer localized-stage disease risk and $0.973(95 \% \mathrm{CI}=0.745-$ 1.272) on prostate cancer advanced-stage disease. The results in the subgroup analysis by geographic locations were not changed. Detailed results are showed in Table 2.

Begg's funnel plots (Fig. 3) and Egger's test $(P=0.296)$ indicated that no publication was found in overall analysis. The sensitivity analysis (Fig. 4) showed that there is no single study that had potential effects on the overall result while removing a study at a time.

\section{Discussion}

The overall analyses suggested that high intake of protein were not related to the risk of prostate cancer. The association was significant on prostate cancer risk neither with animal protein intake nor with vegetable protein intake. We did not find any relationship between geographic locations and study design and prostate cancer risk. 
43921 articles found from Web of Knowledge

61591 articles found from PubMed

341 articles found from $\mathrm{CNKI}$

412 articles found from Wan Fang Med Online

72163 articles screened after excluding duplicates

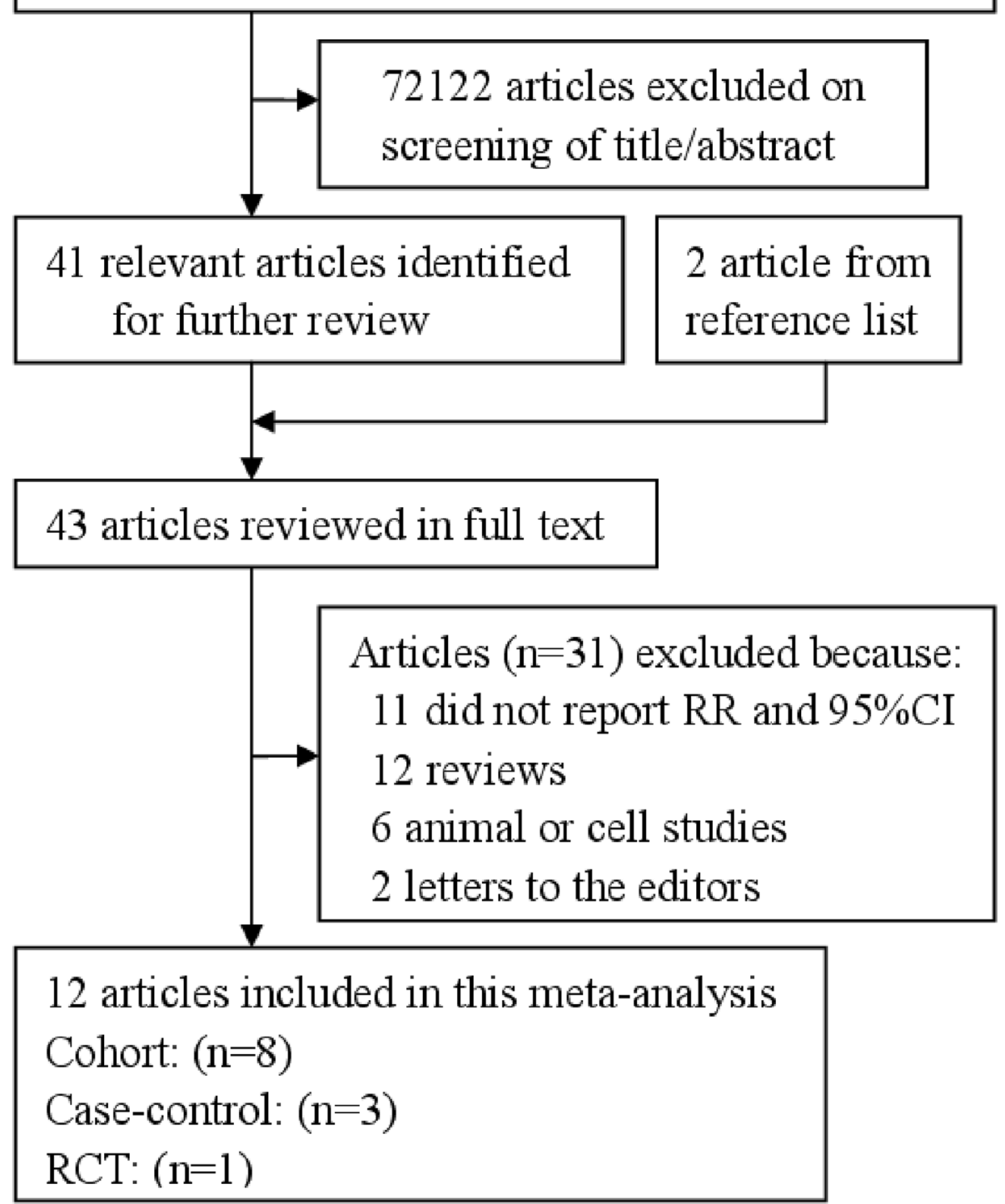

Fig. 1 Study selection process for this meta-analysis

Protein is an important nutrient for the human body, which is essential for body growth and development, as well as the transport of many important substances.
Protein deficiency can lead to growth retardation, nutritional edema, or may even endanger life [25]. Meat is an important source of protein. A previous publication of 


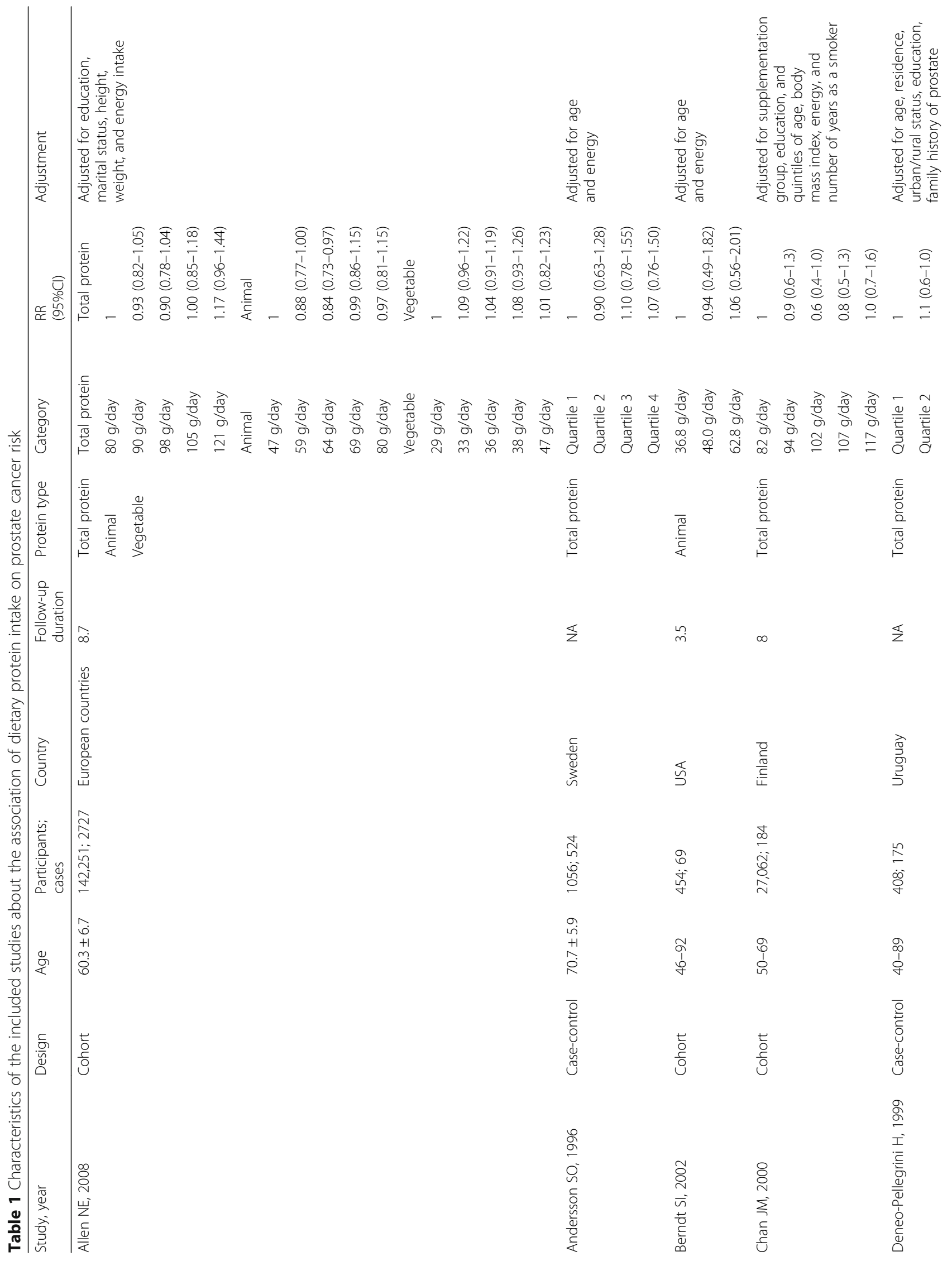




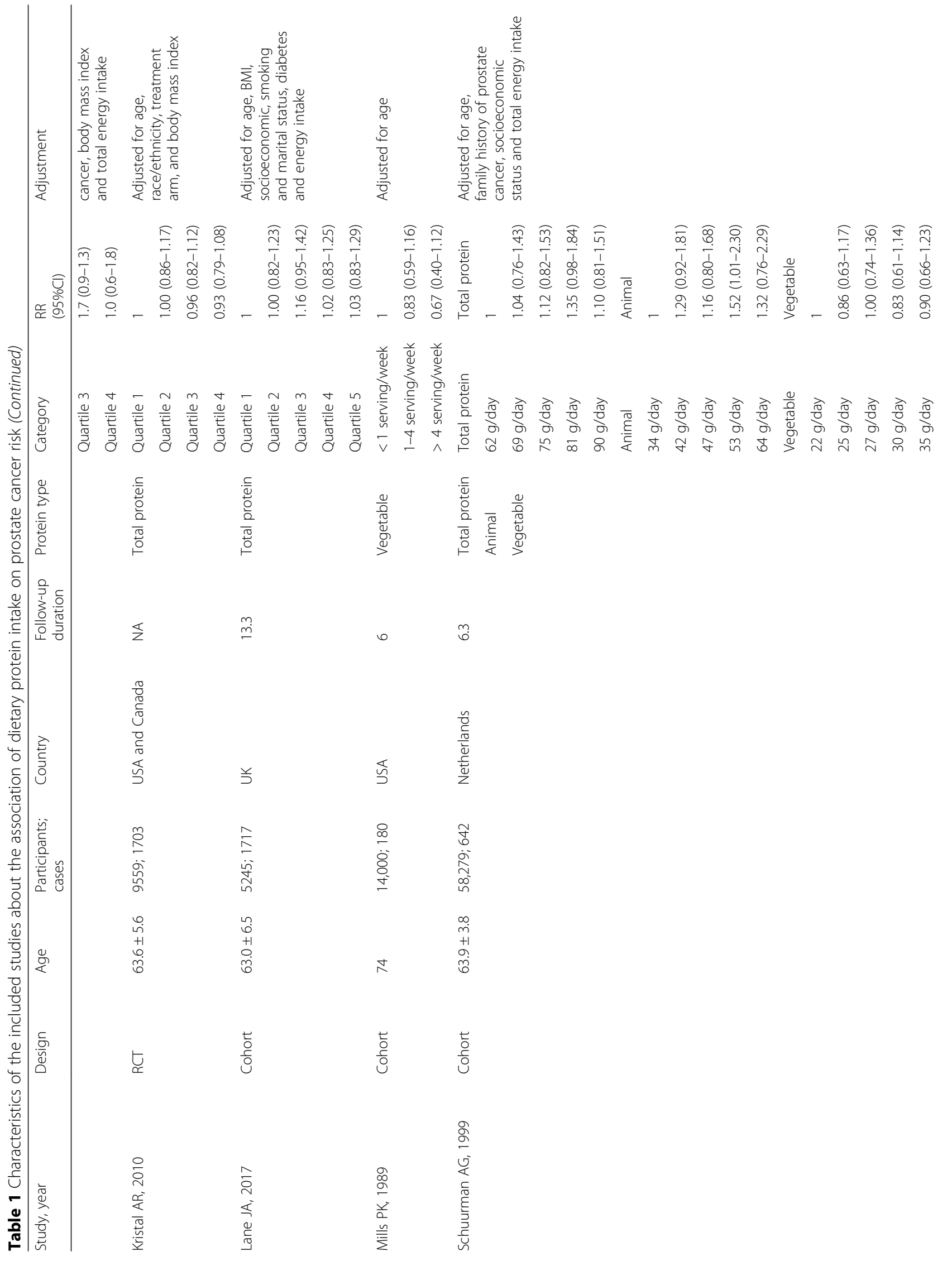




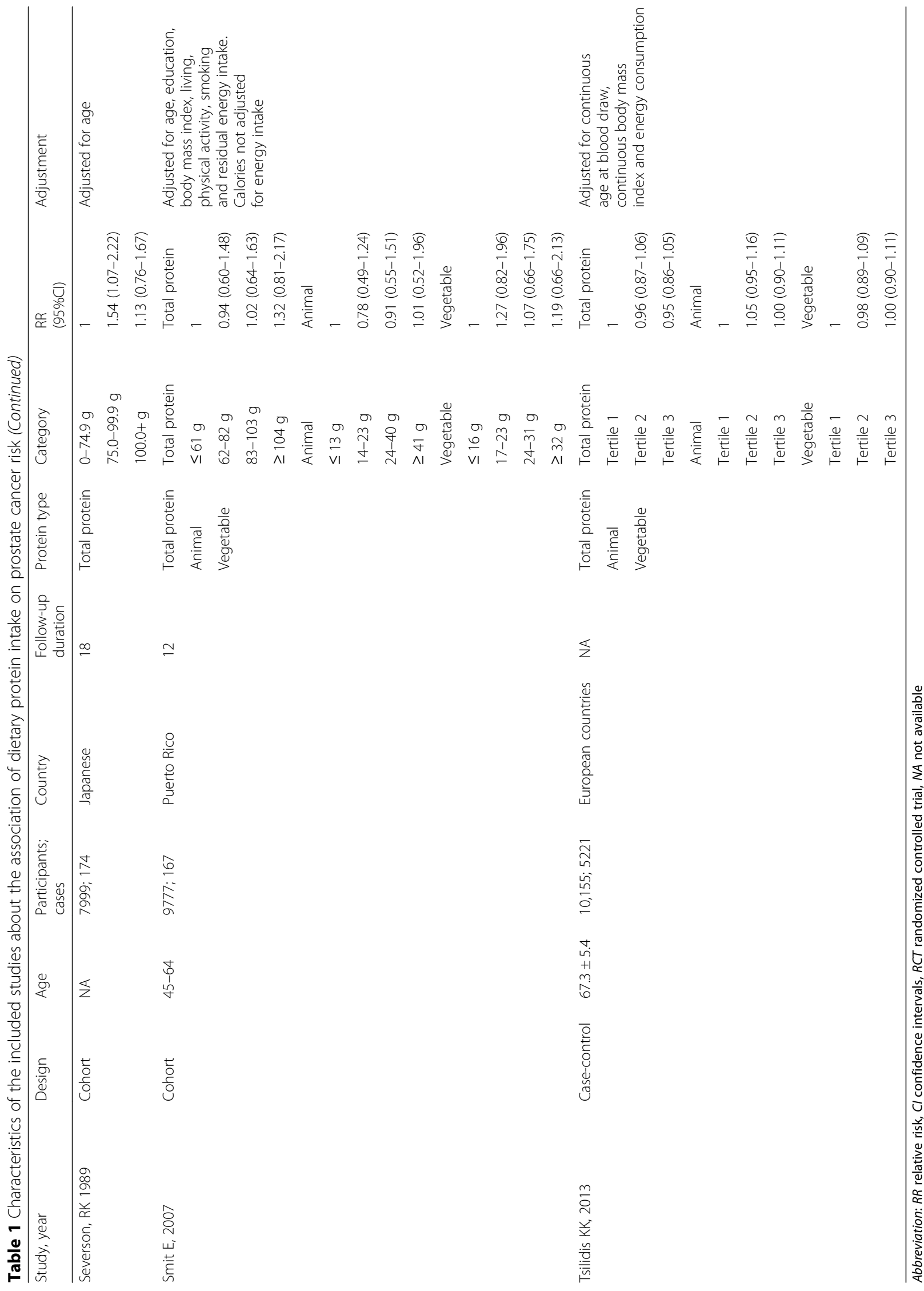




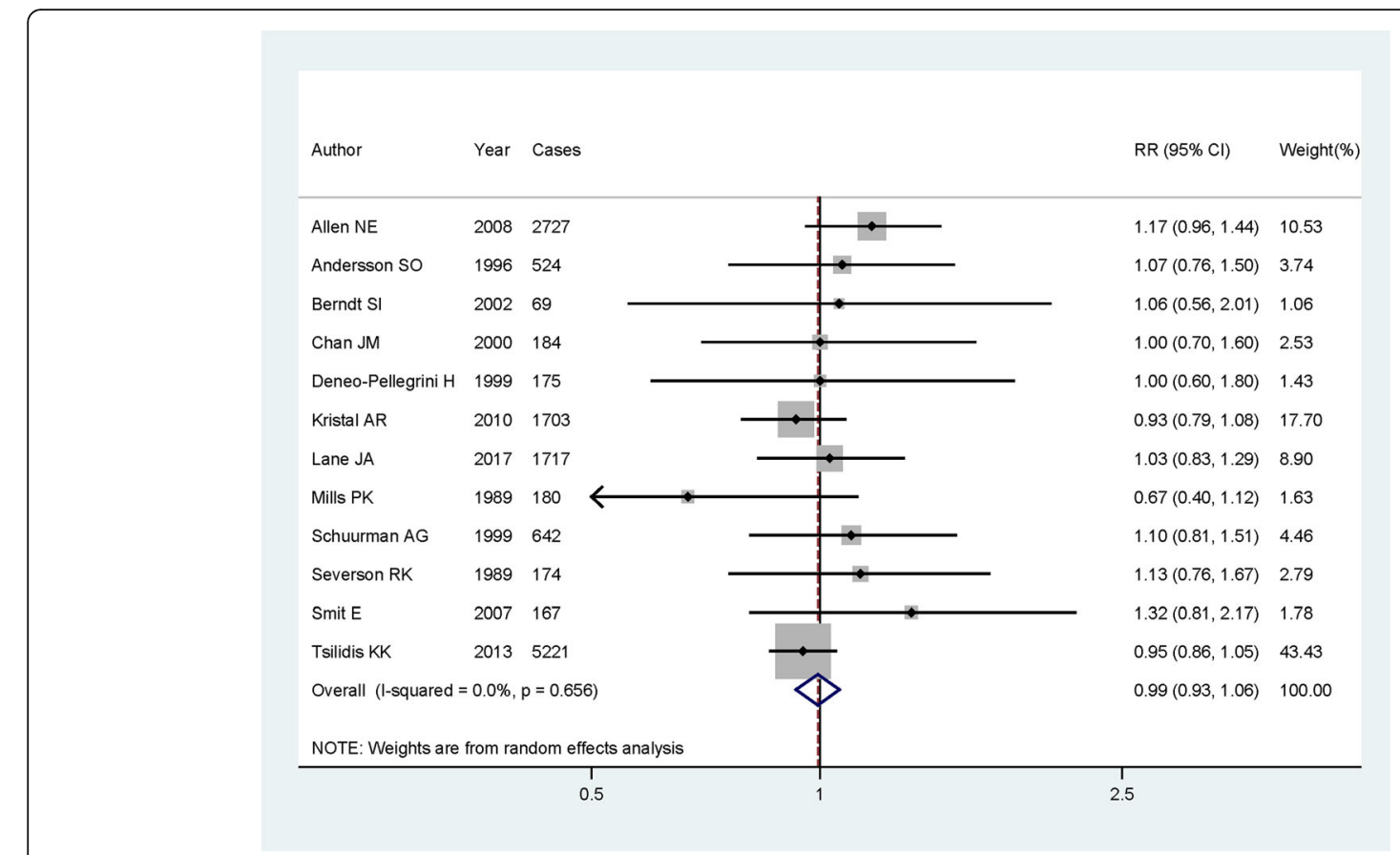

Fig. 2 Forest plot for assessment of association between dietary protein intake and risk of prostate cancer

meta-analysis was performed to explore the association on dietary meat intake for prostate cancer risk. No significant relationships were found on prostate cancer either in total red meat consumption or fresh red meat consumption, while higher processed meat consumption could increase the risk of prostate cancer [26]. In our studies, we did not obtain a positive result for prostate cancer with animal protein intake, which is consistent with the above result. Soy food is another source of protein. A study of meta-analysis suggested that soy food consumption could decrease the risk of prostate cancer [27]. The reason for this result may be that soy foods contain many fibers and phytoestrogens that block the cell cycle, induce apoptosis, and inhibit angiogenesis.

Table 2 Summary RR and $95 \% \mathrm{Cl}$ of the association between dietary protein intake and prostate cancer risk

\begin{tabular}{|c|c|c|c|c|c|c|}
\hline \multirow[t]{2}{*}{ Subgroups } & \multirow{2}{*}{$\begin{array}{l}\text { Number } \\
\text { of } \\
\text { studies }\end{array}$} & \multirow[t]{2}{*}{ RR } & \multirow[t]{2}{*}{$95 \% \mathrm{Cl}$} & \multirow{2}{*}{$\begin{array}{l}P \text { for } \\
\text { trend }\end{array}$} & \multicolumn{2}{|c|}{ Heterogeneity test } \\
\hline & & & & & $P$ & $R^{2}(\%)$ \\
\hline Overall & 12 & 0.993 & $0.930-1.061$ & 0.841 & 0.656 & 0.0 \\
\hline \multicolumn{7}{|l|}{ Protein type } \\
\hline Animal protein & 5 & 1.001 & $0.917-1.092$ & 0.988 & 0.891 & 0.0 \\
\hline Vegetable protein & 5 & 0.986 & $0.904-1.076$ & 0.753 & 0.556 & 0.0 \\
\hline \multicolumn{7}{|l|}{ Study design } \\
\hline Cohort & 8 & 1.080 & $0.964-1.209$ & 0.184 & 0.670 & 0.0 \\
\hline Case-control & 3 & 0.960 & $0.874-1.055$ & 0.399 & 0.797 & 0.0 \\
\hline $\mathrm{RCT}$ & 1 & - & - & - & - & - \\
\hline \multicolumn{7}{|l|}{ Cancer type } \\
\hline Localized-stage disease & 2 & 1.263 & $0.953-1.674$ & 0.103 & 0.508 & 0.0 \\
\hline Advanced-stage disease & 3 & 0.973 & $0.745-1.272$ & 0.843 & 0.703 & 0.0 \\
\hline \multicolumn{7}{|l|}{ Geographic locations } \\
\hline Europe & 6 & 1.005 & $0.931-1.085$ & 0.899 & 0.566 & 0.0 \\
\hline America & 5 & 0.943 & $0.824-1.080$ & 0.397 & 0.450 & 0.0 \\
\hline Asia & 1 & - & - & - & - & - \\
\hline
\end{tabular}


Funnel plot with pseudo $95 \%$ confidence limits

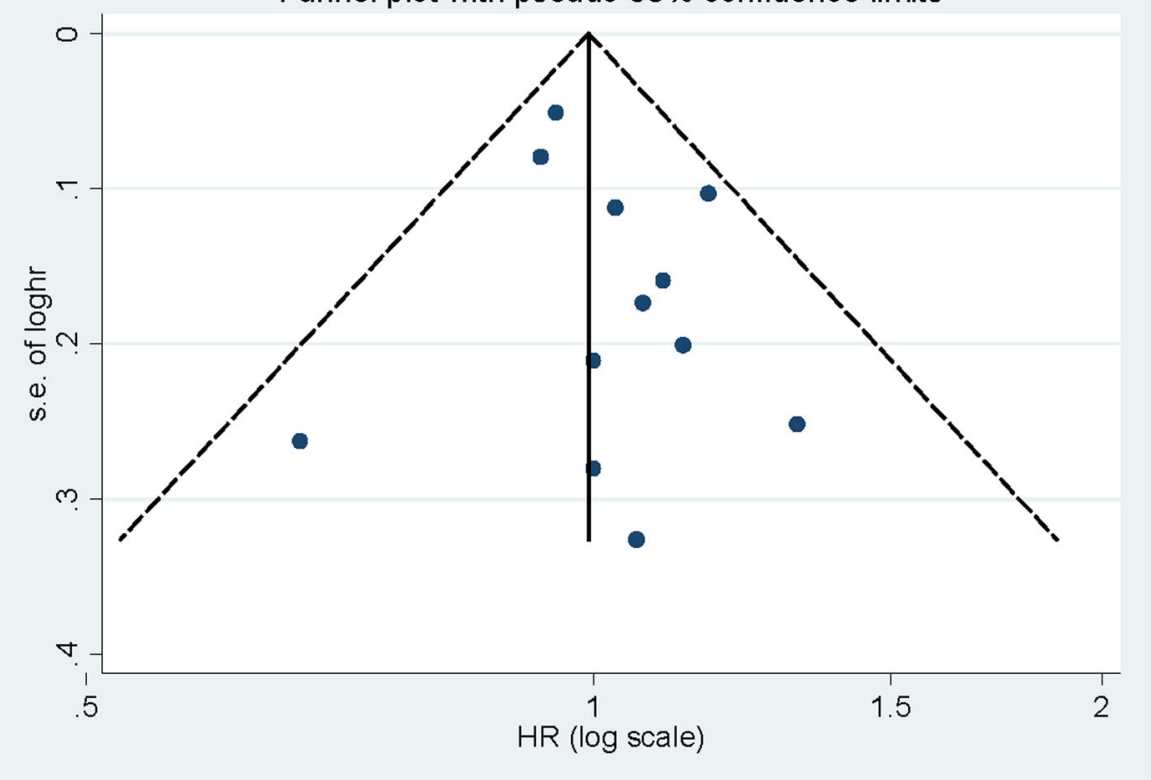

Fig. 3 Funnel plot for assessment of publication bias

Therefore, these mechanisms may support the point that higher category of dietary soy foods intake could reduce the risk of prostate cancer [25]. However, we cannot conclude a reverse relation between vegetable protein and prostate cancer risk. Furthermore, a recent meta-analysis suggested a nonsignificant association on colorectal cancer risk while in high-protein intake [28], as consistent with our results.

The most relevant risk factors on prostate cancer risk had been addressed. Previous study indicated that there was a slight association between metabolic syndrome and prostate cancer $(\mathrm{RR}=1.17,95 \% \mathrm{CI}=1.00-1.36, P=0.04)$ [29]. Results from 11 cohort studies found that diabetes

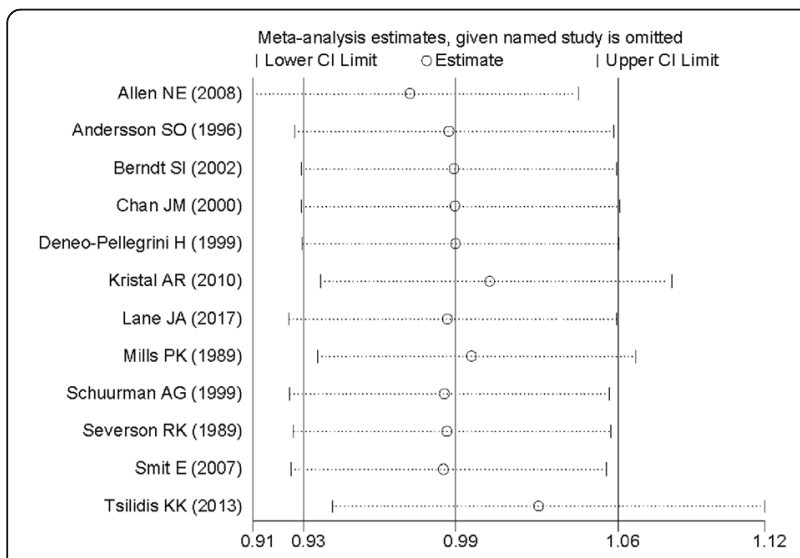

Fig. 4 Sensitivity analysis of the association between dietary protein intake and prostate cancer risk mellitus could significantly increase the incidence of prostate cancer [30]. However, a meta-analysis of 14 prospective studies concluded that cholesterol level in blood was not associated with the risk of prostate cancer [31].

Our study had some strength. Firstly, large numbers of cases and participants were included in this study, yielding a more comprehensive result. Secondly, no between-study heterogeneity was found either in the whole analysis or in the subgroup analyses in this study and this may obtain a stable result. Thirdly, the small study effect was not detected using Begg's funnel plots and Egger's test in our analysis.

To our attention, some potential limitations exited in our report. Firstly, only English or Chinese language publications were searched and all suitable studies were English articles, this may omit some other languages publications. However, no publication bias was found. Secondly, most studies included in this report were European or American populations, and we found significant association neither in European populations nor in American populations. As we know, although the results were consistent in different subgroup analyses by racial, men of African descent showed a high incidence of prostate cancer and it may make some difference [32]. Furthermore, there exists a gap in the knowledge with lower risk populations where dietary or environmental risk may play a disproportionate impact (for example, incidence of prostate cancer is lower in Asians than in Caucasians or African Americans in the USA; however, the incidence of prostate cancer in Asian Americans, 
while lower than that in Caucasians, is nonetheless higher than that in East Asians). Thus, more studies conducted in other countries should be performed to further assess the association on prostate cancer risk with protein intake. Thirdly, three of the included studies followed with case-control design may lead to inherent recall and selection bias of retrospective studies. Although different kinds of studies were included, we did subgroup analysis to exclude the interruption. There is no significant relation between prostate cancer and study design. Fourth, as understanding of prostate cancer growth, genetics, and the natural history of the disease has grown, subsidiary questions are increasingly important. Given the commonality of low-risk disease and evidence of over treatment, a more refined question to be asked is the association with high-grade or intermediate or high-risk disease. Therefore, more refined studies are wanted to answer these questions due to the data from an epidemiological standpoint that does not exist to support such analysis.

\section{Conclusions}

In conclusions, findings from this meta-analysis concluded that there is no effect on prostate cancer with high-protein intake. Since some limitations exited in our study, future studies are wanted to confirm the result.

\section{Abbreviations \\ Cl: Confidence intervals; RCTs: Randomized controlled trials; RR: Relative risk}

\section{Authors' contributions}

YM, YT, and JD are the guarantors of integrity of the entire study who contributed to the definition of intellectual content, data acquisition, data analysis, statistical analysis, and review of the manuscript. JD conceived the concepts of the study. JD and YM contributed to the study design and helped in literature research. YM conducted the clinical and experimental studies and prepared the manuscript. YM and $Y T$ edited the manuscript. All authors read and approved the final manuscript.

\section{Ethics approval and consent to participate}

Not applicable.

\section{Consent for publication}

Not applicable.

\section{Competing interests}

The authors declare that they have no competing interests.

\section{Publisher's Note}

Springer Nature remains neutral with regard to jurisdictional claims in published maps and institutional affiliations.

Received: 16 March 2018 Accepted: 17 July 2018

Published online: 24 July 2018

\section{References}

1. Center MM, Jemal A, Lortet-Tieulent J, et al. International variation in prostate cancer incidence and mortality rates. Eur Urol. 2012;61(6):1079-92.

2. Siegel RL, Miller KD, Jemal A. Cancer statistics, 2017. CA Cancer J Clin. 2017; $67(1): 7-30$.
3. Lopez Fontana CM, Recalde Rincon GM, Messina Lombino D, et al. Body mass index and diet affect prostate cancer development. Actas Urologicas Espanolas. 2009;33(7):741-6.

4. Wu K, Hu FB, Willett WC, et al. Dietary patterns and risk of prostate cancer in U.S. men. Cancer Epidemiol Biomarkers Prev. 2006;15(1):167-71.

5. Montagnese C, Santarpia L, lavarone F, et al. North and South American countries food-based dietary guidelines: a comparison. Nutrition. 2017; 42:51-63.

6. Aronson WJ, Barnard RJ, Freedland SJ, et al. Growth inhibitory effect of low fat diet on prostate cancer cells: results of a prospective, randomized dietary intervention trial in men with prostate cancer. J Urol. 2010;183(1):345-50.

7. Masko EM, Allott EH, Freedland SJ. The relationship between nutrition and prostate cancer: is more always better? Eur Urol. 2013;63(5):810-20.

8. DerSimonian R, Laird N. Meta-analysis in clinical trials. Control Clin Trials. 1986;7(3):177-88.

9. Higgins JP, Thompson SG, Deeks JJ, et al. Measuring inconsistency in metaanalyses. BMJ. 2003:327(7414):557-60.

10. Higgins JP, Thompson SG. Controlling the risk of spurious findings from meta-regression. Stat Med. 2004:23(11):1663-82.

11. Egger M, Davey Smith G, Schneider M, et al. Bias in meta-analysis detected by a simple, graphical test. BMJ. 1997;315(7109):629-34.

12. Begg CB, Mazumdar M. Operating characteristics of a rank correlation test for publication bias. Biometrics. 1994:50(4):1088-101.

13. Allen NE, Key TJ, Appleby PN, et al. Animal foods, protein, calcium and prostate cancer risk: the European Prospective Investigation into Cancer and Nutrition. Br J Cancer. 2008;98(9):1574-81.

14. Andersson SO, Wolk A, Bergstrom R, et al. Energy, nutrient intake and prostate cancer risk: a population-based case-control study in Sweden. Int J Cancer. 1996;68(6):716-22.

15. Berndt SI, Carter HB, Landis PK, et al. Calcium intake and prostate cancer risk in a long-term aging study: the Baltimore Longitudinal Study of Aging. Urology. 2002;60(6):1118-23.

16. Chan JM, Pietinen $P$, Virtanen $M$, et al. Diet and prostate cancer risk in a cohort of smokers, with a specific focus on calcium and phosphorus (Finland). Cancer Causes Control. 2000;11(9):859-67.

17. Deneo-Pellegrini H, De Stefani E, Ronco A, et al. Foods, nutrients and prostate cancer: a case-control study in Uruguay. Br J Cancer. 1999;80(3-4):591-7.

18. Kristal AR, Arnold KB, Neuhouser ML, et al. Diet, supplement use, and prostate cancer risk: results from the prostate cancer prevention trial. Am J Epidemiol. 2010;172(5):566-77.

19. Lane JA, Oliver SE, Appleby PN, et al. Prostate cancer risk related to foods, food groups, macronutrients and micronutrients derived from the UK Dietary Cohort Consortium food diaries. Eur J Clin Nutr. 2017;71(2):274-83.

20. Mills PK, Beeson WL, Phillips RL, et al. Cohort study of diet, lifestyle, and prostate cancer in Adventist men. Cancer. 1989;64(3):598-604.

21. Severson RK, Nomura AM, Grove JS, et al. A prospective study of demographics, diet, and prostate cancer among men of Japanese ancestry in Hawaii. Cancer Res. 1989;49(7):1857-60.

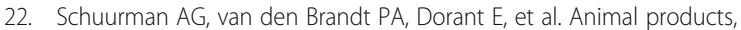
calcium and protein and prostate cancer risk in The Netherlands Cohort Study. Br J Cancer. 1999:80(7):1107-13.

23. Smit E, Garcia-Palmieri MR, Figueroa NR, et al. Protein and legume intake and prostate cancer mortality in Puerto Rican men. Nutr Cancer. 2007; 58(2):146-52

24. Tsilidis KK, Travis RC, Appleby PN, et al. Insulin-like growth factor pathway genes and blood concentrations, dietary protein and risk of prostate cancer in the $\mathrm{NCl}$ Breast and Prostate Cancer Cohort Consortium (BPC3). Int J Cancer. 2013;133(2):495-504

25. Wu J, Zeng R, Huang J, et al. Dietary protein sources and incidence of breast cancer: a dose-response meta-analysis of prospective studies. Nutrients. 2016;8(11).

26. Bylsma LC, Alexander DD. A review and meta-analysis of prospective studies of red and processed meat, meat cooking methods, heme iron, heterocyclic amines and prostate cancer. Nutr J. 2015:14:125.

27. Hwang YW, Kim SY, Jee SH, et al. Soy food consumption and risk of prostate cancer: a meta-analysis of observational studies. Nutr Cancer. 2009; 61(5):598-606

28. Lai R, Bian Z, Lin H, et al. The association between dietary protein intake and colorectal cancer risk: a meta-analysis. World J Surg Oncol. 2017;15(1):169.

29. Gacci M, Russo Gl, De Nunzio C, et al. Meta-analysis of metabolic syndrome and prostate cancer. Prostate Cancer Prostatic Dis. 2017;20(2):146-55. 
30. Cai $H, X u Z, X u T$, et al. Diabetes mellitus is associated with elevated risk of mortality amongst patients with prostate cancer: a meta-analysis of 11 cohort studies. Diabetes Metab Res Rev. 2015;31(4):336-43.

31. YuPeng $L$, YuXue Z, PengFei $L$, et al. Cholesterol levels in blood and the risk of prostate cancer: a meta-analysis of 14 prospective studies. Cancer Epidemiol Biomarkers Prev. 2015;24(7):1086-93.

32. Ferlay J, Soerjomataram I, Dikshit R, et al. Cancer incidence and mortality worldwide: sources, methods and major patterns in GLOBOCAN 2012. Int $J$ Cancer. 2015;136(5):E359-86.

- fast, convenient online submission

- thorough peer review by experienced researchers in your field

- rapid publication on acceptance

- support for research data, including large and complex data types

- gold Open Access which fosters wider collaboration and increased citations

- maximum visibility for your research: over $100 \mathrm{M}$ website views per year

At $\mathrm{BMC}$, research is always in progress. 